\title{
Analysis of Organic Rice Farming in Nguter District, Sukoharjo Regency
}

\author{
Catur Rini Sulistyaningsih \\ Universitas Veteran Bangun Nusantara \\ Sukoharjo, Indonesia \\ scaturrini@yahoo.com
}

\begin{abstract}
This aim of the research is to find out the amount of costs, revenues, profits, profitability, efficiency and risk of organic rice farming in the district of Nguter, sukoharjo regency. The basic research method used is descriptive analytical method. The determination of the sample area of the respondents was done intentionally (purposively) namely District Nguter Sukoharjo Regency. Sampling of respondents is done in a way census. Respondents are all farmers who manage organic rice in the District Nguter Sukoharjo District. The respondents were 32 people. Data used are primary data and secondary data. The data collection techniques are carried out with observation, interview, and recording. The results of this study indicate that the total costs the average organic rice farming business in Nguter District, Sukoharjo Regency is amount IDR 6,581,405.25 The average revenue obtained is IDR $17,690,240.63$. So the average profit obtained by organic farmers is IDR $11,108,834.38$. While the profitability of organic rice farming in Nguter District, Sukoharjo Regency is $168.79 \%$, which means that organic rice farming is profitable. Farming Organic rice in the Nguter District of Sukoharjo Regency has more efficiency than one is 2.69. This means that every IDR 1.00 spent by farmers on the start of farming activities will get IDR 2.69 times the cost issued at the end of the farming activity. Organic rice farming in the District Nguter Sukoharjo Regency has a coefficient of variation (CV) of more than 0.5 that is equal to 0.68 and the lower limit of profit $(L)$ is - IDR 3,946,388.86 so that high-risk organic rice farming with the possibility of loss is IDR 3- 946,388.85.
\end{abstract}

Keywords-efficiency, organic rice, profit, risk

\section{INTRODUCTION}

Indonesia is an agrarian country where most of the population lives and depends on the agricultural sector. The role of the agricultural sector in national economic development is very important because most members of society in agrarian countries such as Indonesia depend their lives on the sector. The agricultural sector still plays an important role in Indonesia. This is evident because in addition to being able to provide employment, the agricultural sector is also a foreign exchange earner through exports and the most important is being able to provide domestic food needs.

Of the various types of food consumed, rice has the first order. It can be said that almost all Indonesians make rice as their main food ingredient [2]. In Indonesia, rice production accounts for around $30 \%$ of the total agricultural sector production. In addition, the rice sector controls $69 \%$ of the harvested area [4]. This further strengthens the evidence that Indonesia is an agricultural country where the economy is still supported by the agricultural sector, especially the rice sector.
Increased food needs encourage agricultural people to increase crop productivity and develop food diversity. Green revolution is one alternative that has been developed as an effort to increase crop productivity. But humans are not aware that the use of chemical fertilizers and pesticides is unwise and due to exploitation, nature then loses its balance which ultimately has a negative impact on humans [1].

Learning from the negative impacts of the use of chemical fertilizers and pesticides, we try to find safe planting techniques, both for the environment and humans. This is what gave birth to organic farming. Organic farming is an agricultural cultivation business that only uses natural materials, both given through soil and directly to cultivated plants. The main characteristic of organic farming is the use of natural varieties that are naturally followed by the use of organic fertilizers and pesticides in terms of health, organic products are safe for human consumption because they are free from residues of harmful substances [1].

Sukoharjo Regency is one of the areas that has potential in the development of rice and is a supplier of rice in the Central Java Province [3]. This is supported by a climate suitable for rice development and the extent of agricultural land, especially rice fields, as well as the availability of water for the development of rice plants.

The growing prevalence of organic farming, Sukoharjo Regency has begun to apply it to various agricultural commodities, including rice as a commodity producing rice as a staple food as a large part of the Indonesian population. The selling price of organic rice is higher than non-organic rice. The productivity of rice that is cultivated organically is also higher than that of rice that is cultivated nonorganically. With such high productivity and selling prices it is expected that recipients and profits from farming will also increase so that it will also increase farmers' household income. Based on this, the authors are interested in conducting a research related to the analysis of organic farming in Nguter District, Sukoharjo Regency. The purpose of this study was to determine the amount of costs, revenues, profits, profitability, efficiency, and risk of organic rice farming in Nguter District, Sukoharjo Regency.

\section{METHODS}

A. The Basic Research Method

The method used in this research is descriptive analytical method. This method has characteristics that research is based on solving actual problems that exist today. The data collected was first compiled, explained, then analyzed. 


\section{B. The Taking Area and Farmer Samples Method}

Determination of the sample area was carried out purposively, namely in the Nguter District, Sukoharjo Regency. The sample selection of organic rice farmers in Nguter District, Sukoharjo Regency was carried out by census, meaning that all populations of organic rice farmers were used as samples. This research was conducted in April - May 2012 with a total of 32 organic rice farmers.

C. The Types and Data Sources

1. Primary data, is data obtained directly from respondents through interviews using a prepared questionnaire.

2. Secondary data, is data obtained from instance or institutions related to this research. The notes come from the Sukoharjo Regency Statistics Center, District offices and village offices, as well as other instance related to this research.

D. The Data Collection Technique

1. Observation is collecting data through direct observation on the object of research.

2. Interview, to get primary data through direct interviews with respondents based on the questionnaire prepared.

3. Recording, to collect primary and secondary data by recording.

\section{E. The Data Analysis Method}

1. Cost, Acceptance, Profitability and Profitability of Organic Rice Farming

$$
\begin{aligned}
& \text { a. Cost } \\
& \mathrm{TC}=\mathrm{TFC}+\mathrm{TVC} \\
& \mathrm{TC}=\text { the total cost of organic rice farming (IDR) } \\
& \mathrm{TFC}=\text { total fixed costs of organic farming (IDR) } \\
& \mathrm{TVC}=\text { total variable cost of organic rice farming } \\
& \text { (IDR) }
\end{aligned}
$$

\section{b.Reception}

$$
\mathrm{TR}=\mathrm{Q} \times \mathrm{P}
$$

$\mathrm{TR}=$ total revenue of organic rice farming (IDR)

$\mathrm{Q}=$ Amount of organic rice production $(\mathrm{kg})$

$\mathrm{P} \quad=$ selling price of organic rice (IDR / Kg)

c.Profit

$$
\pi=\mathrm{TR}-\mathrm{TC}
$$

$\pi \quad=$ profit of organic rice farming (IDR)

$\mathrm{TR}=$ total revenue of organic rice farming (IDR)

$\mathrm{TC}=$ total cost of organic rice farming (IDR)

$$
\begin{aligned}
& \text { d.Profitability } \\
& \quad \begin{aligned}
& \text { Profitability }=\pi / \mathrm{TC} \times 100 \% \\
\pi & =\text { profit of organic rice farming (IDR) } \\
\mathrm{TC} \quad & =\text { total cost of organic rice farming (IDR) }
\end{aligned}
\end{aligned}
$$

The criteria used in the calculation of profitability are as follows:

Profitability > 0 means profitable organic rice farming.

Profitability $=0$, meaning that organic rice farming experiences BEP (breakeven).
Profitability $<0$ means that organic rice farming is not profitable.

2. Business Efficiency

$$
\text { Efficiency }=\mathrm{R} / \mathrm{C}
$$

$\mathrm{R}=$ acceptance of organic farming rice business (IDR)

$\mathrm{C}=$ total cost of organic farming (IDR)

Criteria for R / C > 1 means that organic rice farming is efficient.

$\mathrm{R} / \mathrm{C}=1$ means that organic rice farming has not been efficient.

$\mathrm{R} / \mathrm{C}<1$ means that organic farming is not efficient.

3. Business risk

a. Coefficient of variation

$$
\mathrm{CV}=\mathrm{V} / \mathrm{E}
$$

$\mathrm{CV}=$ coefficient of variation in organic rice farming

$\mathrm{V}=$ standard deposit of organic rice farming (IDR)

$\mathrm{E} \quad=$ average profit of organic rice farming (IDR)

b.Average profit of farming

$$
E=\frac{\sum_{i=1}^{n} E_{i}}{n}
$$

$\mathrm{E}=$ average profit of organic rice farming (IDR)

E1 = benefits of organic rice farming received by farmers (IDR)

$\mathrm{N}$ = number of organic rice farmers (people)

c.Standard deposit using the variance analysis method

$$
\mathrm{V}=\sqrt{V^{2}} \text { and } \mathrm{V} 2=\frac{\sum_{i=1}^{\mathrm{n}}\left(E_{\mathrm{i}}-E\right)^{2}}{(n-1)}
$$

$\mathrm{V}=$ variety

$\mathrm{N}$ = number of samples of organic rice farmers (people)

$\mathrm{E} \quad=$ average profit of organic rice farming (IDR)

$\mathrm{E} 1=$ the benefits of organic rice farming received by farmers (IDR)

d.Lower limit of profit

$$
\mathrm{L}=\mathrm{E}-2 \mathrm{~V}
$$

$\mathrm{L}=$ lower limit of profit of organic rice farming (IDR)

$\mathrm{E}=$ average profit of organic rice farming (IDR)

$\mathrm{V}=$ standard deposit of organic rice farming (IDR)

The higher of $\mathrm{CV}$ value indicates that the risk of organic rice farming must be borne by the larger farmers. The criteria used are if the $C V$ value $\leq 0.5$ and $L \geq 0$ states that organic rice farming has a low risk and organic rice farmers will always avoid losses. If the $\mathrm{CV}$ value $>0.5$ and $\mathrm{L}<0$ means that organic rice farming has a high risk and there is a chance of loss that will be suffered by organic rice farmers. 


\section{RESULT AND DISCUSSION}

\section{A. The Characteristics of Respondents of Organic Rice} Farming

Characteristics of respondents are a general description of the circumstances and background of small farmers who are related to and at the same time influence their activities in the organic rice farming business. Respondents in this study were organic rice farmers who at the time of the study were still active in organic rice farming and domiciled in Nguter District, Sukoharjo District.

Table 1. Characteristics of respondents of organic rice farming in Nguter District, Sukoharjo District

\begin{tabular}{lll}
\hline No & Description & Average per farmer \\
\hline 1 & Number of farmers respondents (people) & 32 \\
2 & Average age of farmer (th) & 52,58 \\
3 & Average farmer education (th) & 9.97 \\
4 & $\begin{array}{l}\text { The average area of paddy field cultivated } \\
\left(\mathrm{m}^{2}\right)\end{array}$ & $6.453,13$ \\
& $\begin{array}{l}\text { Average experience in organic rice farming } \\
\text { (th) }\end{array}$ & 7,32 \\
\end{tabular}

Source: primary data analysis

Based on Table 1, it can be seen that the average element of organic farmers is $\mathbf{5 2 . 5 8}$ ths which means it is included in the productive age. In this productive age, the work productivity of organic rice farmers is still high enough so that it is more potential in running its business. Most organic rice farmers in Nguter District, Sukoharjo Regency had received formal education, which is an average of 9.97 ths. This shows that almost most respondents received education up to junior high school level. Although formal education does not become a necessary condition in organic rice farming, it will affect the mindset of organic rice farmers in making their farming decisions. Organic rice farming has been going on for a long time, this is evidenced by the length of business experience owned by businesses owned by farmers, which averaged around 7.32 ths. The longer the time worked, the more experience the farmers gained and the amount of experience the farmers had would be useful to overcome the various business constraints they faced.

Table 2. Status of organic rice farming in Nguter District, Sukoharjo Regency

\begin{tabular}{llll}
\hline No. & Business & $\begin{array}{l}\text { Amount } \\
\text { (respondent) }\end{array}$ & $\begin{array}{l}\text { Percentage } \\
(\%)\end{array}$ \\
\hline 1. & Status & 26 & 81,25 \\
2. & Main & 6 & 18,75 \\
\hline & Side & 32 & 100,00
\end{tabular}

Source: primary data analysis

Table 2 shows that the majority of respondents, amounting to 26 respondents $(81.25 \%)$ make this organic rice farming as the main business because they are able to provide sufficient income to pump their daily needs and can be used as capital to carry out organic rice farming Nguter District, Sukoharjo Regency. In addition, there were 6 respondents $(18.75 \%)$ who ran organic rice farming business only as a side business. Other businesses include village equipment, repair shops, penebas, ricemill. They make organic rice farming a side business in the hope of obtaining additional income.

\section{B. The Use of Production Facilities and The Labors}

The use of production facilities and the labor of organic rice farming is shown in Table 3 and Table 4.

Table 3. The average use of production facilities for organic rice farming in Nguter District, Sukoharjo District

\begin{tabular}{|c|c|c|}
\hline No & Description & Average Per Farmer \\
\hline 1. & Seed $(\mathrm{kg})$ & 27,97 \\
\hline \multirow[t]{7}{*}{2.} & Fertilizer & \\
\hline & a. Petroganic $(\mathrm{kg})$ & 15,63 \\
\hline & b. Manure $(\mathrm{kg})$ & 887,50 \\
\hline & c. Bhokasi (kg) & 625,00 \\
\hline & POC (it) & 3,13 \\
\hline & e. Urea $(\mathrm{kg})$ & 74,22 \\
\hline & Phonska (kg) & 142,97 \\
\hline \multirow[t]{8}{*}{3.} & Pesticides & \\
\hline & a. Herbicide & 6,25 \\
\hline & Nabati (it) & 0,03 \\
\hline & Hayati (it) & 0,03 \\
\hline & Bevveria B. (it) & 1,53 \\
\hline & PGPR (it) & 0,41 \\
\hline & f. Coryne Bacterium (it) & 1,44 \\
\hline & g. Ursaplus (it) & 0,19 \\
\hline \multirow[t]{5}{*}{4.} & Others & \\
\hline & a. Plant Vitamins (it) & 1,28 \\
\hline & b. Score $(\mathrm{cc})$ & 15,63 \\
\hline & c. Hexa (it) & 0,02 \\
\hline & MOL (it) & 0,19 \\
\hline
\end{tabular}

Source: primary data analysis

Based on Table 3, it can be seen that organic rice farmers in Nguter District, Sukoharjo Regency use $27.97 \mathrm{~kg}$ of seeds. The seeds used by the farmers are obtained by buying the seeds of the Saprodi Shop that is closest to the farmers' dominance. But there is a small portion of the seeds obtained from their own cultivation, leaving the previous harvest. Organic rice farmers in Nguter district, Sukoharjo Regency, mostly use IR-64 rice varieties, Situ Bagendit, Pepe, Ciherang, Inpari 13, and Pandan Wangi.

The average use of organic fertilizer in organic farming businesses is $887.50 \mathrm{~kg}$ of manure, $15.63 \mathrm{~kg}$ of petroganic fertilizer, $625.00 \mathrm{~kg}$ of bhocation fertilizer, and 3.13 liters of liquid organic fertilizer. The use of organic fertilizer is expected to increase soil fertility and increase the productivity of organic rice produced by farmers in Nguter District, Sukoharjo Regency.

Pests that often attack organic rice plants in Nguter district, Sukoharjo Regency are pests and snails. To overcome these pest attacks farmers use organic pesticides. The average use of organic pesticides by farmers isBevveria bassiana of 1.53 liters, Coryne bacterium of 1.44 liters, biological pesticides of 0.03 liters, vegetable pesticides of 0.03 liters, ursaplus of 0.19 liters, and herbicides $6,25 \mathrm{cc}$. The use of pesticides by organic rice farmers is used to eradicate pests and diseases that attack rice plants, and eradicate weeds that grow around rice plants so it can increase the productivity of organic rice.

Organic rice farmers in Nguter District, Sukoharjo Regency also use other production facilities, namely plant vitamins of 1.28 liters, a score of $15.63 \mathrm{cc}$. Hexa is 0.022 liters, and MOL is 0.19 liters. The use of this production facility is expected to accelerate growth and maintain organic rice plants so that organic rice production can increase. 
Table 4. The average use of organic rice farming labor in Nguter District, Sukoharjo Regency

\begin{tabular}{lllll}
\hline \multirow{2}{*}{ No } & Description & $\begin{array}{l}\text { Average } \\
\text { family } \\
\text { labor }\end{array}$ & $\begin{array}{l}\text { outside } \\
\text { labor }\end{array}$ & \\
\hline 1 & Land Management I & 2,06 & 3,94 & $6,00$. \\
2 & Land Management II & $0,03$. & $4,00$. & $4,03$. \\
3 & Seedbed & $1,41$. & $1,78$. & $3,19$. \\
4 & Planting & $0,75$. & $10,28$. & $11,03$. \\
5 & Fertilization I & $1,78$. & $1,97$. & $3,75$. \\
6 & Fertilization II & $0,58$. & $0,66$. & $1,22$. \\
7 & Fertilization III & $0,44$. & $0,59$. & $1,03$. \\
8 & Weeding I & $3,28$. & $4,94$. & $7,22$. \\
9 & Weeding II & $0,47$. & $1,59$. & $2,06$. \\
10 & Pest Control I & $0,59$. & $0,69$. & $1,28$. \\
11 & Pest Control II & $0,59$. & $0,66$. & $1,28$. \\
12 & Irrigation I & $0,00$. & $0,00$. & $0,00$. \\
13 & Irrigation II & $0,00$. & $0,00$. & $0,00$. \\
14 & Irrigation III & $0,00$. & $0,00$. & $0,00$. \\
15 & Irrigation IV & $0,00$. & $0,00$. & $0,00$. \\
16 & Harvesting & $0,06$. & $17,5$. & $17,56$. \\
17 & Transport & $0,22$. & $2,5$. & $2,72$. \\
\hline Total & & 11,24 & 51,10 & 62,34 \\
\hline Sournnnn & & & & \\
\hline
\end{tabular}

Source: primary data analysis

The workforce of organic rice farming business comes from two sources, namely family labor and outside labor. The total family workforce used in organic rice farming as much as 11.24 and outside labor as much as 51.10 , so the number of workers employed is 62.34. The use of outside labor is greater than the family workforce. This is because family labor does not cover the completion of activities in organic rice farming because in one farmer family, usually only two members are active in farming activities.

Farming activities that mostly use labor are planting, weeding and harvesting activities. Planting activities require a lot of workforce so that the activity is quickly completed considering the age of the seed is directed towards rice productivity. If you are too young, it will spread to pests, while if you are too old, the roots are strong. For weeding activities, the need for labor depends on many or fewer weeds. While the use of organic fertilizer will increase soil fertility which also accelerates the development of weeds. Harvesting activities also require a large number of workers carried out by a group of harvesting farmers who have made an agreement with the owner's farm. Workers who need the most harvesting activities to complete harvesting activities.

\section{The Costs of Organic Rice Farming}

The costs of organic rice farming are listed in Table 5. Table 5. Average cost of production facilities for organic rice farming in Nguter District, Sukoharjo Regency

\begin{tabular}{cll}
\hline No & Description & Average Cost (IDR) \\
\hline 1. & Seed & $211.812,50$ \\
2. & Fertilizer & \\
& a. Petroganic & $10.000,00$ \\
& b. Manure & $350.625,00$ \\
& c. Bhokasi & $31,250,00$ \\
& d. POC & $5.468,75$ \\
& e. Urea & $137.843,75$ \\
f. Phonska & $333.968,75$ \\
& Pesticides & \\
& a. Herbicide $\quad$ Nabati & $2.812,50$ \\
b. Hayati & 937,50 \\
& c. Hevveria Bassiana & $1.562,50$ \\
d. Bo, $\quad 325,00$ \\
e. PGPR & $8.125,00$ \\
f. Coryne Bacterium & $29.687,50$ \\
g. Ursaplus & $2.812,50$
\end{tabular}

\begin{tabular}{ll} 
4. Others & \\
a. Plant Vitamins & $75.625,00$ \\
b. Score & $15.562,50$ \\
c. Heksa & $3.125,00$ \\
d. MOL & $6.562,50$ \\
\hline
\end{tabular}

Source: primary data analysis

The seeds used in organic rice farming in Nguter District, Sukoharjo Regency, were obtained by buying seeds at the Saprodi Shop closest to the farmers' domicile. However there are some seeds obtained from their own cultivation. The average cost incurred by farmers to buy seeds is IDR $211,812.50$.

Organic rice farming costs IDR 350,625.00 to purchase the largest manure compared to other fertilizers. This is because organic rice farmers tend to increase manure because farmers consider that more manure is given so the land becomes fertile.

In organic pesticides, farmers incur greater costs for pesticides Bevveria Bassiana and Coryne Bacterium compared to other natural pesticides, which are an average of $30 \mathrm{~m}$ is IDR 625.00 for Bevveria Bassiana pesticides and an average of IDR 29,687.50 for Coryne Bacterium pesticides. The average cost incurred by organic rice farmers in Nguter District Sukoharjo Regency to buy plant vitamins is IDR $75,625.00$. The provision of plant vitamins is expected to accelerate the growth of rice plants so as to increase organic rice production.

Table 6. Average labor costs of organic rice farming in Nguter District, Sukoharjo Regency

\begin{tabular}{llr}
\hline No & Description & Average cost (IDR) \\
\hline 1 & Land Management I & $298.437,50$ \\
2 & Land Management II & $200.000,00$ \\
3 & Seedbed & $158.125,00$ \\
4 & Planting & $500.625,00$ \\
5 & Fertilization I & $186.875,00$ \\
6 & Fertilization II & $60.625,00$ \\
7 & Fertilization III & $51.562,50$ \\
8 & Weeding I & $355.312,50$ \\
9 & Weeding II & $102.500,00$ \\
10 & Pest Control I & $62.187,50$ \\
11 & Pest Control II & $60.937,50$ \\
12 & Irrigation I & 0,00 \\
13 & Irrigation II & 0,00 \\
14 & Irrigation III & 0,00 \\
15 & Irrigation IV & 0,00 \\
16 & Harvesting & $857,500,00$ \\
17 & Transport & $135.000,00$ \\
\hline Total & & $3.029 .687,50$ \\
\hline
\end{tabular}

Source: primary data analysis

Based on Table 6, it can be seen that organic rice farming activities in Nguter district, Sukoharjo Regency which spend a lot of labor costs are planting, weeding and harvesting activities. The average labor cost for planting activities is IDR 500,625.00. Planting activities cost a lot of money because it requires a lot of labor so that the activity is quickly completed given the age of the seed affects the productivity of rice. For weeding activities, the average farmer costs IDR $355,312.50$. The labor need for weeding depends on many or fewer weeds. If weeds are more and more, the labor will also increase so that the costs incurred will also increase. The 
biggest expenditure is for harvesting activities. This is because harvesting activities require a lot of labor so that harvesting activities are quickly completed.

Table 7. Average cost of other organic rice farming in Nguter District, Sukoharjo Regency

\begin{tabular}{llr}
\hline No & Description & Average cost (IDR) \\
\hline 1 & Land tax & $103.937,50$ \\
2 & Land rent & $1.929 .687,50$ \\
3 & Irrigation Grants & $40.937,50$ \\
4 & Selamatan & 0,00 \\
5 & Transport & $218.750,00$ \\
\hline & Total & $2.293 .312,00$ \\
\hline
\end{tabular}

Source: primary data analysis

Based on Table 7, the biggest cost is land rent, which is an average of IDR 1,929,687.50. The amount of tax on land leases issued by farmers depends on the fertility of the land and the location of the rice fields with the landowner's house. The average cost of irrigation contributions issued by farmers is IDR 40,937.50. The amount of irrigation fees also depends on the agreement between farmers in an area and calculating the area of land owned by farmers. Organic rice farmers in Nguter district, Sukoharjo regency do not pay a selamatan because farmers have thought modernly, in the sense that they believe that the high organic rice production produced depends on their own efforts.

Table 8. Average of total organic rice farming in Nguter District, Sukoharjo Regency

\begin{tabular}{lll}
\hline No & Costs & Description (IDR) \\
\hline 1 & Production facilities & $1.258 .406,25$ \\
2 & Labors & $3.029 .687,50$ \\
3 & Others & $2.293 .312,50$ \\
\hline & Total & $6.581 .406,25$ \\
\hline
\end{tabular}

Source: primary data analysis

Organic rice farming in Nguter district, Sukoharjo Regency, need costs to purchase production facilities, labor costs and other costs. The largest cost is for labor costs of IDR 3,029,687.50. In this workforce plays an important role in organic rice farming, because all of organic rice farming activities are carried out by humans. Based on Table 8 . it can be seen that the total cost is IDR 6,581,406.25. The amount of the total costs will later affect the amount of revenue and profits received by farmers.

\section{The Income of organic rice farming}

The income of organic rice farming is shown in Table 9.

Table 9. Average income of organic rice farming in Nguter District, Sukoharjo Regency

\begin{tabular}{lll}
\hline No & Description & Average \\
\hline 1. & Production (IDR) & $5.505,84$ \\
2. & Price (IDR/ Kg) & $3.212,50$ \\
\hline & Income (IDR) & $17.690 .240,63$ \\
\hline
\end{tabular}

Source: primary data analysis

Based on Table 9, it can be seen that the average organic rice production is $5,505.84 \mathrm{~kg}$. Farmers usually sell crops that are still in the form of dry grain to middlemen or traders collecting an average price of IDR $3,212.50$ so that the average income of organic rice farmers is IDR $17,690,240.63$. The amount of revenue is influenced by the amount of organic rice production produced by farmers, namely the more organic rice produced, the greater the acceptance of farmers.

Table 10. Advantages of organic rice farming in District Nguter District, Sukoharjo Regency

\begin{tabular}{lll}
\hline No & Description & Average (IDR) \\
\hline 1. & Income & $17.690 .240,63$ \\
2. & Total cost & $6.581 .406,25$ \\
\hline \multicolumn{2}{l}{ Source: primary data analysis }
\end{tabular}

Table 10. Shows that the average income of organic rice farmers is IDR 17,690,240.63 with an average total cost of IDR $6,581,406.25$ so that the average profit obtained by organic rice farmers is IDR 11,108. 834.38. The benefits received by organic rice farmers are influenced by the difference in the amount of rice produced, the selling price, and the costs incurred. The more organic rice produced at a low cost and the higher the selling price of organic rice, the greater the profits earned by farmers.

\section{E. The Profitability of Organic Rice Farming}

The profitability of organic rice farming is shown in Table 11

Table 11. Profitability of organic rice farming in Nguter District, Sukoharjo Regency

\begin{tabular}{lll}
\hline No & Description & Average \\
\hline 1. & Profit (IDR) & $11.108 .834,28$ \\
2. & Total cost (IDR) & $6.581 .406,25$ \\
\hline & Profitability (\%) & $168,79 \%$ \\
\hline
\end{tabular}

Source: primary data analysis

Table 11 shows that the profitability or profitability of organic rice farming in Nguter District, Sukoharjo Regency is $168.79 \%$. This means that every capital of IDR 100.00 invested will get a profit of IDR 168.79. Thus, this organic rice farming business is included in the favorable criteria because it has a profitability value of more than zero.

\section{F. The Efficiency of Organic Rice Farming}

The efficiency of organic rice farming is shown in Table 12

Table 12. Efficiency of organic rice farming in Nguter District, Sukoharjo Regency

\begin{tabular}{lll}
\hline No & Description & Average per farmer \\
\hline 1. & Acceptance (IDR) & $17.600 .240,63$ \\
2. & Total cost (IDR) & $6.581 .406,25$ \\
\hline & Business efficiency & 2,69 \\
\hline
\end{tabular}

Source: primary data analysis

Table 12 shows that the efficiency of organic rice farming in Nguter District, Sukoharjo Regency is 2.69, meaning that organic rice farming that has been carried out in Nguter District, Sukoharjo Regency is efficient, which is shown by the $\mathrm{R} / \mathrm{C}$ ratio of more than one.

The R / C ratio of 2.69 means that every IDR 1.00 the cost incurred in an initial business activity gives an income of 2.69 times the costs incurred. While the large $\mathrm{R} / \mathrm{C}$ ratio, the greater the income that farmers will get. 


\section{G. The Ratio of Organic Rice Farming}

The ratio of organic rice farming is shown in Table 13.

Table 13. Business ratio and lower limit of the advantages of organic rice farming in Nguter District, Sukoharjo Regency

\begin{tabular}{lll}
\hline No & Description & Average per farmer \\
\hline 1. & Profit (IDR) & $11.108 .834,38$ \\
2. & Standard deposit (IDR) & $7.527 .611,62$ \\
3. & The coefficient of variation & 0,68 \\
4. & Lower limit of profit (IDR) & $-3.946 .388,86$ \\
\hline
\end{tabular}

Source: primary data analysis

Table 13 shows that the average profit received by organic rice farmers in Nguter District, Sukoharjo Regency was IDR 11,108,834.38. According to the calculation of these benefits, it can be known the amount of standard organic rice farming business savings, which is IDR 7,527,611.62. Standard deposit is the amount of profit fluctuations obtained, so it can be said that the fluctuations in the profit of organic rice farming in Nguter District, Sukoharjo Regency must dare to bear losses of IDR 3,946,388.86.

The coefficient of variation of organic rice farming is 0.68 . This indicates that the organic rice farming community is at high risk, because the coefficient of variation obtained is greater than the standard coefficient of variation of 0.5 . The high coefficient value of this variation is because the value of the profit is quite fluctual, so this affects the value of the standard savings or the amount of risk borne by organic rice farmers. The lower limit of farming profits is IDR 3,946,388.86. This figure shows that organic rice farmers in Nguter Subdistrict, Sukoharjo Regency must be brave enough to lose IDR 3,946,388.86.

\section{CONCLUSION}

Based on the results of research and analysis that has been done, it can be concluded as follows:

1. The total average cost of organic rice farming in Nguter District, Sukoharjo Regency is IDR 6,581,406.25. The average revenue obtained was IDR $17,690,240.63$ so that the average profit obtained by organic rice farmers was IDR 11,108,834.38. While the profitability of organic rice farming in Nguter District, Sukoharjo Regency is $168.79 \%$, which means that organic rice farming is profitable. If at the beginning of the farm the farmers spend IDR 100,000.00, the farmer will get a profit of IDR 168,790.00.

2. Organic rice farming in Nguter District, Sukoharjo Regency has more than one efficiency value, which is 2.69. This means that every IDR 1.00 spent by farmers at the start of farming activities will receive 2.69 times the cost of the farm at the end of the farm. If the farmer at the beginning of the farming activity costs IDR100,000.00, the farmer will receive IDR 269,000.00.

3. Organic rice farming in Nguter district, Sukoharjo Regency has a value coefficient of variation $(\mathrm{CV})$ of more than 0.5 that is equal to 0.68 and a lower limit of profit (L) value of - IDR 3,946,388.86 so that organic rice farming is risky high with a possible loss of IDR $3,946,388.86$.

\section{ACKNOWLEDGMENT}

The author would like to thank the Veteran Bangun Nusantara University of Sukoharjo for providing funds through the APBU (University Expenditure Budget) to carry out a Comprehensive Research in the Field of Science.

REFERENCES

[1] Andoko, Agus. Budidaya Padi Secara Organik. Penebar Swadaya. Jakart, 2002.

[2] Bahrin Samad dan Harjono. Bercocok Tanam Padi. CV Yasaguna. Jakarta, 1998

[3] BPS. Sukoharjo Dalam Angka 2010. Badan Pusat Statistik. Sukoharjo, 2010.

[4] Dumairy . Perekonomian Indonesia. Erlanggga. Jakarta, 1997. 